\title{
PERAN KESADARAN MEREK (BRAND AWARENESS) DALAM MEMEDIASI HUBUNGAN IKLAN OPPO DENGAN NIAT BELI KONSUMEN
}

\author{
I Wayan Dicky Reza Pranata ${ }^{1}$ \\ Km. Agus Satria Pramudana ${ }^{2}$ \\ ${ }^{1,2}$ Fakultas Ekonomi dan Bisnis Universitas Udayana, Bali, Indonesia \\ e-mail: dickyreza96@gmail.com
}

\begin{abstract}
ABSTRAK
Tujuan penelitian ini adalah untuk menguji peran kesadaran merek (brand awareness) dalam memediasi hubungan iklan dengan niat beli konsumen. Penelitian ini dilakukan di Kota Denpasar. Jumlah sampel yang diambil sebanyak 105 responden, dengan metode non probability sampling, khususnya purposive sampling. Pengumpulan data dilakukan melalui metode survei dengan menggunakan instrumen kuesioner. Teknik analisis data yang digunakan adalah Path Analysis. Berdasarkan hasil analisis ditemukan bahwa iklan berpengaruh secara positif dan signifikan terhadap kesadaran merek (brand awareness). Penelitian ini juga menemukan bahwa masing-masing variabel iklan dan kesadaran merek (brand awareness) berpengaruh secara positif dan signifikan terhadap niat beli konsumen. Selain itu kesadaran merek (brand awareness) juga secara positif dan signifikan memediasi hubungan iklan dengan niat beli konsumen. Hal ini menunjukkan bahwa semakin menarik iklan smartphone Oppo serta semakin tinggi kesadaran merek (brand awareness) dalam benak konsumen maka akan meningkatkan niat beli konsumen pada smartphone Oppo.
\end{abstract}

Kata kunci: iklan, kesadaran merek (brand awareness), niat beli.

\begin{abstract}
The purpose of this study is to examine the role of brand awareness in mediating advertising relationships with consumers' buying intentions. This research was conducted in Denpasar City. The number of samples taken as many as 105 respondents, with the method of nonprobability sampling, especially purposive sampling. Data collection was done through survey method using questionnaire instrument. Data analysis technique used is Path Analysis. Based on the analysis results found that the ads have a positive and significant impact on brand awareness. The study also found that each of the ad variables and brand awareness has a positive and significant impact on consumers' buying intentions. In addition brand awareness (brand awareness) also positively and significantly mediate ad relationship with consumer purchase intention. This indicates that the more interesting the Oppo smartphone ads and the higher brand awareness in the minds of consumers will increase consumer intention to buy on Oppo smartphones.
\end{abstract}

Keywords: advertising, brand awareness purchase intention. 


\section{PENDAHULUAN}

Salah satu perusahaan yang baru merambah bisnis smartphone adalah OPPO Electronics Corp, Ltd. OPPO Electronics Corp, Ltd. merupakan perusahaan yang menciptakan smartphone dengan merek Oppo. OPPO Electronics Corp, Ltd. merupakan perusahaan yang terbilang baru, dimana perusahaan tersebut didirikan pada tahun 2004 tetapi baru memasuki pasar smartphone pada tahun 2008 (www.oppo.com). OPPO Electronics Corp, Ltd. merupakan perusahaan yang berbasis di Dongguang, Guangdong, China. OPPO Electronics Corp, Ltd. tidak hanya menciptakan smartphone saja, beberapa produk yang diciptakan selain smartphone antara lain, LCD TV, e-book, pemutar DVD, dan MP3 player. Pada tahun 2013 Oppo Electronics Corp, Ltd. resmi memasuki pasar smartphone di Indonesia. Smartphone merek Oppo di Indonesia walaupun terbilang baru, selama kurun waktu 5 tahun sudah mampu menempati peringkat 2 sebagai merek smartphone yang paling terkenal di Indonesia.

Kesuksesan smartphone merek Oppo sendiri tidak terlepas dari inovasi dan perkembangan smartphone Oppo yang selalu mengikuti trend perkembangan pasar dan permintaan pasar, seperti trend smartphone dengan rasio layar smartphone yaitu 18:9 serta permintaan pasar akan smartphone dengan kamera yang handal dan mampu mengasilkan foto selfie yang jernih (Oppo F5). Hal yang tidak kalah pentingnya adalah harga yang ditawarkan pada setiap smartphone Oppo sesuai dengan fitur-fitur yang didapatkan pada smartphone tersebut. Beragam fitur-fitur dan keunikan yang dimiliki sebuah smartphone tidak selalu menjadi sebuah faktor kunci yang mempengaruhi pembelian konsumen akan sebuah smartphone. Tidak jarang pembelian konsumen akan sebuah smartphone dipengaruhi oleh faktor lain 
selain keunikan serta fitur-fitur yang dimiliki sebuah smartphone. Penting bagi perusahaan untuk mengetahui faktor-faktor apa saja yang mempengaruhi niat beli konsumen tersebut.

Niat beli adalah tahap dimana konsumen dalam membentuk pilihan mereka diantara beberapa merek yang tergabung dalam perangkat pilihan, kemudian pada akhirnya melakukan suatu pembelian pada suatu alternatif yang paling disukainya atau proses yang dilalui konsumen untuk membeli suatu barang atau jasa yang didasari oleh bermacam pertimbangan (Annafik dkk., 2012). Niat membeli dapat digunakan untuk memprediksi perilaku yang akan datang. Artinya bila konsumen menunjukkan niat membeli yang tinggi maka dapat diduga bahwa ia akan melakukan pembelian aktual. Pemasar berkepentingan untuk mengidentifikasi niat beli konsumen (Suprapti, 2010: 148). Melalui pengidentifikasian niat beli konsumen maka produsen smartphone akan dapat untuk menentukan faktor-faktor apa saja yang dapat mempengaruhi niat beli konsumen tersebut yang selanjutnya dapat digunakan oleh produsen smartphone untuk menyusun strategi-strategi tepat. Apabila strategi yang digunakan sudah tepat dan efektif maka produsen smartphone akan mampu menghadapi persaingan yang semakin kompetitif yang pada akhirnya mampu meningkatkan niat beli konsumen akan produk yang diproduksinya. Adanya niat beli yang tinggi tersebut membuat peluang konsumen untuk melakukan pembelian terhadap suatu produk akan semakin tinggi.

Swastha dan Irawan (2005: 349) mengemukakan faktor-faktor yang mempengaruhi niat membeli berhubungan dengan perasaan emosi, bila seseorang merasa senang dan puas dalam membeli barang atau jasa maka hal itu akan 
memperkuat niat beli, kegagalan biasanya menghilangkan niat beli. Pengaruh dari luar diri seseorang juga dapat mempengaruhi niat beli. Pengaruh eksternal tersebut terdiri dari usaha pemasaran dan faktor sosial budaya (Schiffman dan Leslie, 2004: 25). Tjiptono (2005: 150), menjelaskan bahwa niat beli dapat ditingkatkan dengan memperhatikan beberapa faktor, antara lain: 1) Faktor psikis, merupakan faktor yang berasal dari dalam diri konsumen, yaitu motivasi, persepsi, pengetahuan, keyakinan, dan sikap yang ada di dalam diri masing-masing individu. 2) Faktor sosial, merupakan proses dimana perilaku seseorang dipengaruhi orang lain dan kebudayaan yang ada di sekitarnya seperti: keluarga, status sosial, dan kelompok acuan. 3) Pemberdayaan bauran pemasaran, faktor ini berasal dari perusahaan yang menjadi produsen terhadap produk yang digunakan oleh konsumen yang terdiri atas: produk, harga, promosi dan distribusi.

Salah satu strategi dari bauran pemasaran yang dapat digunakan oleh produsen smartphone untuk meningkatkan niat beli konsumen adalah melalui pengiklanan produk. Iklan merupakan suatu bentuk pesan/informasi yang disampaikan kepada masyarakat luas mengenai suatu produk atau jasa. Iklan adalah seluruh jenis komunikasi yang mengacu pada seluruh bentuk teknik komunikasikomunikasi yang digunakan pemasar untuk menyampaikan sebuah pesan kepada konsumen (Prabawa dkk., 2017). Menurut Kotler dan Keller (2012: 526), iklan dapat menjadi cara yang efektif untuk menyebarkan pesan, baik untuk membangun preferensi merek atau untuk mendidik masyarakat. Menggunakan strategi pengiklanan produk yang tepat akan membuat konsumen menjadi lebih mengetahui dan memahami tentang produk yang diproduksi oleh suatu perusahaan. 
Pengetahuan dan pemahaman yang diperoleh konsumen tentang produk suatu perusahaan akan menciptakan suatu kesadaran konsumen akan suatu merek dari sebuah produk, yang dalam istilah pemasaran disebut dengan kesadaran merek (brand awareness). Hal tersebut ditegaskan oleh penelitian yang dilakukan oleh (Gunawan dan Diah, 2014) yang mengatakan bahwa iklan sebagai media promosi terbukti memiliki hubungan positif signifikan serta berperan penting meningkatkan kesadaran merek (brand awareness). Penelitian tersebut didukung oleh (Sukma dkk., 2015); (Herdana, 2015); (Charanah dan Njuguna, 2015) yang mengatakan bahwa efektivitas iklan berpengaruh secara positif dan signifikan dengan peningkatan kesadaran merek (brand awareness).

Kesadaran merek (brand awareness) adalah kemampuan merek yang muncul di benak konsumen ketika mereka berpikir tentang produk tertentu dan seberapa mudah bahwa produk muncul (Hasbun dan Endang, 2016). Merek memegang peranan penting dalam peningkatan niat beli konsumen. Semakin tinggi kesadaran konsumen akan suatu merek maka akan semakin besar pula potensi produk suatu perusahaan untuk di beli oleh konsumen. Penanaman dan penciptaan suatu ingatan akan merek pada benak konsumen sangat penting dalam upaya untuk meningkatkan niat beli konsumen akan suatu produk. Adanya kesadaran akan merek pada suatu produk membuat konsumen cenderung mempercayai produk tersebut dalam benaknya sehingga mampu memunculkan niat beli terhadap suatu produk. Hal tersebut sesuai dengan yang dipaparkan oleh Andrologi (2014) yang mengatakan bahwa salah satu bentuk dari kesadaran merek (brand awareness) adalah sebuah 
merek yang dikenal dan mempunyai kemungkinan untuk bisa diandalkan, dan kualitasnya bisa dipertanggungjawabkan.

Berdasarkan penelitian sebelumnya yang dilakukan oleh Prabawa dkk. (2017) yang berjudul "Peran Brand Awareness dalam memediasi Hubungan Iklan dan Personal Selling dengan Niat Beli" mengatakan bahwa iklan dan personal selling berpengaruh positif dan signifikan terhadap niat beli, dimana potensi terjadinya niat beli terhadap produk dari suatu perusahaan akan tinggi jika iklan dan personal selling yang dibuat perusahaan semakin menarik. Temuan selanjutnya yaitu mengatakan bahwa kesadaran merek (brand awareness) berpengaruh signifikan dan positif terhadap niat beli dan secara keseluruhan, baik iklan, personal selling dan kesadaran merek (brand awareness) mempengaruhi dan menentukan niat beli konsumen. Penelitian tersebut didukung oleh Husein dkk. (2017) mengatakan bahwa iklan berpengaruh positif dan signifikan terhadap niat beli. Begitu pula penelitian yang dilakukan oleh Fatmawati dan Yoestini (2012) yang menemukan bahwa iklan sangat berpengaruh positif dan signifikan dengan pembentukan sebuah kesadaran merek (brand awareness).

Terdapat juga penelitian yang menemukan hal sebaliknya, seperti penelitian yang dilakukan oleh Wibowo dan Nurhadi (2017) menemukan bahwa efektivitas iklan tidak berpengaruh terhadap niat beli. Penelitian yang dilakukan oleh Swisstiani (2014) juga mengatakan bahwa efektivitas iklan internet tidak memiliki pengaruh yang signifikan terhadap niat beli. Penelitian yang dilakukan oleh Keke (2015) juga menemukan bahwa iklan tidak berpengaruh signifikan terhadap kesadaran merek (brand awareness), serta penelitian yang dilakukan oleh Susilo 
dan Hatane (2015) yang mengatakan bahwa kesadaran merek (brand awareness) berpengaruf positif terhadap niat beli tetapi tidak signifikan. Adanya research gap tersebut membuat penelitian tentang peran kesadaran merek (brand awareness) dalam memediasi hubungan iklan Oppo dengan niat beli konsumen dengan studi yang dilakukan pada smartphone Oppo di Kota Denpasar menarik untuk diteliti. Merek Oppo dianggap menarik dijadikan sebagai subyek penelitian karena dilihat dari kesuksesan smartphone merek Oppo yang terbilang baru dalam merambah bisnis smartphone Indonesia, tetapi dalam kurun waktu 5 tahun sudah mampu menempati peringkat 2 dalam top brand index smartphone di Indonesia.

Niat beli diangkat sebagai variabel terikat dalam penelitian ini karena niat beli merupakan variabel yang sangat penting untuk diidentifikasi. Melalui pengidentifikasian niat beli maka akan diketahui faktor-faktor apa saja yang mempengaruhi niat beli tersebut, kemudian dari informasi dan pengetahuan yang diperoleh maka dapat disusun strategi pemasaran yang tepat sehingga mampu memotivasi konsumen potensial untuk melakukan pembelian aktual.

Kota Denpasar dijadikan sebagai lokasi penelitian karena Kota Denpasar merupakan salah satu kota dengan penduduk terpadat di Bali dengan jumlah penduduk mencapai angka 636.599 jiwa pada tahun 2016 (www.denpasarkota.go.id). Kota Denpasar juga merupakan ibu kota Provinsi Bali serta Kota Denpasar memiliki komposisi penduduk yang heterogen, dimana penduduk yang menetap di Kota Denpasar berasal dari daerah lain di Provinsi Bali, sehingga diharapkan dengan melakukan penelitian di Kota Denpasar dapat mewakili seluruh masyarakat yang ada di Provinsi Bali. 
Iklan adalah suatu bentuk pesan yang disampaikan kepada masyarakat luas dengan menggunakan suatu media. Istilah periklanan merujuk kepada pemahaman keseluruhan proses yang meliputi persiapan, perencanaan, pelaksanaan, dan pengawasan penyampaian pesan (Niken, 2007: 127). Menurut Tjiptono (2005: 226), iklan adalah bentuk komunikasi tidak langsung yang didasari informasi tentang keunggulan atau keuntungan suatu produk yang disusun sedemikian rupa sehingga menimbulkan rasa menyenangkan yang mengubah pikiran seseorang untuk melakukan pembelian. Sramova (2015) juga mendefinikan iklan, yaitu sebagai presentasi produk dan jasa kepada masyarakat umum, untuk menginformasikan produk secara lebih jelas. Iklan juga adalah komunikasi persuasif yang dibiayai dengan menggunakan media massa nonpersonal yang sama baiknya dengan bentuk komunikasi interaktif lainnya untuk meraih pemirsa dalam jumlah besar secara meluas yang digunakan sebagai penghubung antara pihak sponsor yang membiayai dengan target khalayaknya (Wells et al., 2006: 5). Secara garis besar, iklan dapat digolongkan menjadi tujuh kategori pokok, yaitu: (1) iklan konsumen, (2) iklan bisnis ke bisnis atau iklan antarbisnis, (3) iklan perdagangan, (4) iklan eceran, (5) iklan keuangan, (6) iklan langsung, dan yang terakhir, (7) iklan lowongan kerja (Jefkins, 1997: 39).

Menurut Aaker (2013: 205), kesadaran merek (brand awareness) adalah sebuah aset yang dapat bertahan dalam waktu yang sangat lama. Kesadaran merek (brand awareness) merupakan aset yang tidak berwujud (intangible asset), yang mencakup merek, persepsi kualitas, nama atau citra, simbol, dan slogan suatu merek yang merupakan sumber utama keunggulan bersaing di masa depan. Menurut Malik 
et al. (2013), kesadaran merek (brand awareness) merupakan sebuah modal yang penting, karena merupakan salah satu faktor yang mempengaruhi keputusan pembelian.

Menyadari akan pentingnya kesadaran merek (brand awareness) dalam mempengaruhi niat beli dan keputusan pembelian konsumen menyebabkan banyak perusahaan yang berlomba-lomba untuk meraih top of mind di benak konsumen, sehingga setiap harinya konsumen disesaki oleh pesan pemasaran di berbagai media yang tujuannya adalah untuk membangun sebuah kesadaran merek (brand awareness).

Niat beli (purchase intention) adalah perilaku konsumen yang muncul sebagai respon terhadap objek yang menunjukkan keinginan pelanggan untuk melakukan pembelian (Kotlet dan Keller, 2012: 137). Niat beli menurut Shah et al. (2012) adalah jenis keputusan yang mempelajari secara khusus mengapa konsumen membeli sebuah merek. Niat beli adalah tahapan konsumen dalam membentuk pilihan mereka diantara beberapa merek yang tergabung dalam perangkat pilihan, kemudian pada akhirnya melakukan suatu pembelian alternatif yang paling disukainya atau proses yang dilalui konsumen untuk membeli suatu barang atau jasa yang didasari oleh bermacam pertimbangan (Annafik dkk., 2012). Niat beli adalah evaluasi dan sikap konsumen terhadap produk dengan melihat faktor eksternal sehingga berdampak pada kesediaan konsumen untuk membeli produk (Wen et al., 2013).

Iklan merupakan salah satu elemen yang memiliki dampak yang sangat tinggi pada ekuitas merek, dibandingkan bauran pemasaran lainnya. Efektivitas iklan 
tergantung dari isi, eksekusi atau bagaimana iklan dalam menyampaikan pesan (Charanah dan Njuguna, 2015). Melalui pengiklanan konsumen akan lebih mengenal produk yang dimiliki oleh suatu perusahaan. Pengenalan produk tersebut kemudian akan menimbulkan kesadaran konsumen akan suatu merek. Sulistyowati (2013) mengatakan bahwa kesadaran merek (brand awareness) merupakan langkah awal untuk membangun sebuah merek produk. Kesadaran merek (brand awareness) meliputi proses mulai dari perasaan tidak mengenal merek itu hingga yakin bahwa merek itu adalah satu-satunya dalam kelas produk atau jasa tertentu.

Bimantoro dan Anita (2011) mengatakan bahwa frekuensi melihat iklan dapat mempengaruhi tingkat kesadaran reponden secara signifikan. Hal tersebut didukung oleh Prabawa dkk. (2017) yang mengatakan bahwa iklan berpengaruh positif dan signifikan terhadap kesadaran merek (brand awareness), dimana jika iklan dari sebuah perusahaan semakin baik, maka potensi kesadaran merek (brand awareness) masyarakat terhadap perusahaan tersebut juga akan semakin meningkat, dan begitu juga sebaliknya.

Menurut Sugiardi dan Harti (2017); Merriska dan Purwanegara (2012); Sawant (2012) menemukan bahwa iklan berpengaruh secara positif dan signifikan terhadap kesadaran merek (brand awareness). Senada dengan penelitian sebelumnya, Karunanity dan Sivesan (2013); Assagaf (2013) juga mengatakan bahwa kesadaran merek (brand awareness) dipengaruhi secara positif dan signifikan oleh promotion mix yang salah satunya yaitu iklan. Hubungan iklan dengan kesadaran merek (brand awareness) juga diperkuat oleh penelitian yang dilakukan oleh Herdana (2015); Charanah dan Njuguna (2015); Sukma dkk. (2015) 
yang mengemukakan bahwa efektifitas iklan berpengaruh secara positif dan signifikan dengan kesadaran merek (brand awareness).

$\mathrm{H}_{1}$ : Iklan berpengaruh secara positif dan signifikan terhadap kesadaran merek (brand awareness).

Iklan adalah bentuk komunikasi tidak langsung yang didasari informasi tentang keunggulan atau keuntungan suatu produk yang disusun sedemikian rupa sehingga menimbulkan rasa menyenangkan yang mengubah pikiran seseorang untuk melakukan pembelian (Tjiptono, 2008: 226). Iklan memiliki empat fungsi utama, yaitu menginformasikan khalayak mengenai seluk beluk produk (informative), mempengaruhi khalayak untuk membeli (persuading), dan menyegarkan informasi yang diterima khalayak (reminding), serta menciptakan suasana yang menyenangkan sewaktu khalayak menerima dan mencerna informasi (entertainment) (Tjiptono, 2008: 226). Iklan merupakan salah satu alat yang efektif dari komunikasi pemasaran terpadu untuk memotivasi emosional konsumen agar membeli sebuah produk tertentu (Priya et al., 2010).

Berdasarkan hasil penelitian yang dilakukan oleh Kalele dkk. (2015) mengatakan bahwa daya tarik iklan berpengaruh signifikan terhadap niat beli konsumen, dimana untuk merangsang niat beli konsumen iklan harus berani menawarkan suatu kreativitas, agar dimata konsumen terlihat berbeda dari iklaniklan lainnya. Penelitian tersebut sejalan dengan penelitian Suharto dkk. (2016) yang mengatakan bahwa secara parsial daya tarik iklan mempunyai pengaruh yang signifikan terhadap niat beli konsumen dengan arah yang positif. Pernyataan tersebut didukung oleh Wibowo dan Nurhadi (2017) yang juga mengatakan bahwa terdapat pengaruh positif efektivitas iklan terhadap niat beli konsumen. Menurut 
Huang dan Hoang (2014); Husein dkk. (2017); Gunawan dan Diah (2014) juga menemukan bahwa iklan berpengaruh positif dan signifikan terhadap niat beli.

$\mathrm{H}_{2}$ : Iklan berpengaruh secara positif dan signifikan terhadap niat beli.

Menurut Aaker (2013: 205), kesadaran merek (brand awareness) adalah sebuah aset yang dapat bertahan dalam waktu yang sangat lama. Kesadaran merek (brand awareness) merupakan aset yang tidak berwujud (intangible asset), yang mencakup merek, persepsi kualitas, nama atau citra, simbol, dan slogan suatu merek yang merupakan sumber utama keunggulan bersaing di masa depan. Menurut Malik et al. (2013), kesadaran merek (brand awareness) merupakan sebuah modal yang penting, karena merupakan salah satu faktor yang mempengaruhi keputusan pembelian.

Penelitian yang dilakukan oleh Iwan dan Kaman (2017); Petahiang et al. (2015) mengatakan bahwa kesadaran merek (brand awareness) memiliki pengaruh yang positif dan signifikan dengan niat beli konsumen. Hasil penelitian yang senada juga dikemukakan oleh Prabawa dkk. (2017) dimana ditemukan bahwa kesadaran merek (brand awareness) secara signifikan berpengaruh positif terhadap niat beli, dimana semakin tinggi kesadaran merek (brand awareness) yang dimiliki oleh konsumen maka akan semakin tinggi pula niat beli konsumen tersebut. Penelitian tersebut didukung oleh penelitian Roozy et al. (2014); Malik et al. (2013); Shah et al. (2012); Yaseen et al. (2011); Jalilvand et al. (2011) yang mengemukakan bahwa kesadaran merek (brand awareness) dapat mempengaruhi niat beli secara positif signifikan.

$\mathrm{H}_{3}$ : Kesadaran merek (brand awareness) berpengaruh secara positif dan signifikan terhadap niat beli. 
Penelitian Sugiardi dan Harti (2017); Meriska dan Purwanegara (2012); Sawant (2012) menemukan bahwa iklan berpengaruh secara positif dan signifikan terhadap kesadaran merek (brand awareness). Hal senada juga disampaikan oleh Odunlami dan Emanuelson (2014); Tulasi (2012) mengatakan bahwa kesadaran merek (brand awareness) dipengaruhi secara positif dan signifikan oleh seluruh elemen promotion mix yang salah satunya yaitu iklan.

Penelitian yang dilakukan oleh (Iwan dan Kaman, 2017) mengatakan bahwa kesadaran merek (brand awareness) memiliki pengaruh yang positif dan signifikan dengan niat beli konsumen. Penelitian tersebut didukung oleh penelitian Roozy et al., 2014; Malik et al., 2013; Shah et al., 2012; Yaseen et al., 2011; Jalilvand et al., 2011 yang mengemukakan bahwa kesadaran merek (brand awareness) dapat mempengaruhi niat beli secara positif signifikan. Secara tidak langsung penelitian yang dilakukan oleh (Prabawa dkk., 2017) yang mengemukakan bahwa kesadaran merek (brand awareness) mampu memediasi hubungan iklan dengan niat beli secara positif dan signifikan.

$\mathrm{H}_{4}$ : Kesadaran merek (brand awareness) berpengaruh secara positif dan signifikan dalam memediasi hubungan iklan dengan niat beli.

\section{METODOLOGI PENELITIAN}

Penelitian ini merupakan penelitian assosiatif yang bertujuan untuk menguji hubungan antara variabel bebas yaitu iklan (X), dengan variabel terikat yaitu niat beli (Y) dan variabel mediasi yaitu kesadaran merek (brand awareness) (M). Penelitian ini akan membahas tentang hubungan iklan dengan kesadaran merek (brand awareness), iklan dengan niat beli, kesadaran merek (brand awareness) 
dengan niat beli, serta akan meneliti variabel mediasi yaitu kesadaran merek (brand awareness) yang akan memediasi hubungan iklan dengan niat beli.

Populasi dari penelitian ini adalah calon konsumen di Kota Denpasar yang ingin membeli produk smartphone Oppo. Sampel dalam penelitian ini adalah calon konsumen di Kota Denpasar yang ingin membeli produk smartphone Oppo serta telah mengetahui iklan smartphone Oppo. Untuk memperoleh data yang valid maka jumlah sampel responden yang diambil dan ditentukan paling sedikit 5-10 kali jumlah indikator (Sugiono, 2014: 130). Penelitian ini menggunakan 15 indikator sehingga dengan menggunakan estimasi berdasarkan jumlah parameter diperoleh ukuran sampel sebesar 75 - 150 responden. Jumlah sampel yang digunakan dalam penelitian ini adalah 105 responden. Jumlah dari responden yang akan diuji di dapat dari hasil perhitungan sebagai berikut:

$$
\begin{aligned}
\text { Jumlah Responden } & =15 \text { indikator } \mathrm{x} 7 \\
& =105 \text { responden }
\end{aligned}
$$

Jumlah sampel ditentukan sebanyak 105 reponden karena dalam penelitian ini menggunakan metode path anlysis, dimana jumlah sampel minimal dalam metode path analysis adalah minimal menggunakan 100 sampel. Jumlah 105 responden tersebut dianggap ideal dalam melakukan penelitian ini, dimana jumlah tersebut mendekati titik tengah antara 75 dan 150 responden.

Metode yang digunakan dalam penelitian ini adalah teknik non probability sampling, yaitu metode sampling yang tidak memberi kesempatan atau peluang yang sama bagi setiap unsur atau populasi untuk dipilih menjadi sampel. Metode pengumpulan data yang digunakan dalam penelitian ini adalah metode survei dengan menggunakan instrumen kuesioner. Kuesioner dibuat dengan menggunakan 
pertanyaan terbuka, yaitu terdiri dari pertanyaan-pertanyaan untuk menjelaskan identitas responden, dan pertanyaan tertutup, yaitu pertanyaan yang meminta responden untuk memilih salah satu jawaban yang tersedia dari setiap pertanyaan. Kuesioner disebarkan di Kota Denpasar dan pengisiannya di dampingi oleh peneliti. Pertanyaan dalam kuesioner dibuat dengan menggunakan skala Likert dari pertanyaan yang diberikan kepada responden.

Teknik analisis data yang digunakan adalah analisis jalur. Analisis jalur digunakan untuk menentukan pola hubungan antara tiga atau lebih dan tidak dapat digunakan untuk mengkonfirmasi atau menolak hipotesis, Aprilisya (2016). Riduwan dan Engkos (2011: 2) mengatakan analisis jalur digunakan untuk menganalisis pola hubungan antar variabel dengan tujuan untuk mengetahui pengaruh langsung maupun tidak langsung seperangkat variabel bebas terhadap variabel terikat.

\section{HASIL PENELITIAN DAN PEMBAHASAN}

Data dalam penelitian ini diperoleh dari 105 responden melalui penyebaran kuesioner secara langsung. Berdasarkan kuesioner yang telah disebarkan, secara garis besar karakteristik responden dapat ditinjau dari beberapa variabel demografi, yaitu melalui variabel jenis kelamin, usia, jenis pekerjaan dan pendidikan terakhir responden. Responden dalam penelitian ini didominasi oleh perempuan, yaitu sebanyak 56 orang (53,3 persen) dan 49 orang ( 46,7 persen) berjenis kelamin lakilaki. Sebagian besar responden dalam penelitian ini adalah berusia diantara 18-22 tahun sebanyak 73 orang (69,5 persen) dan sisanya berusia 23-27 tahun sebanyak 15 orang (14,3 persen), berusia $28-32$ tahun sebanyak 3 orang (2,9 persen), berusia 
33-37 tahun sebanyak 1 orang (0,9 persen), berusia 38-42 sebanyak 1 orang $(0,9$ persen), dan responden yang berusia diatas 42 tahun sebanyak 12 orang (11,5 persen).

Pekerjaan responden mayoritas masih berstatus pelajar/mahasiswa yaitu sebanyak 72 orang $(68,6$ persen), sedangkan sisanya memiliki pekerjaan sebagai karyawan swasta sebanyak 16 orang (15,2 persen), PNS sebanyak 1 orang $(0,9$ persen), pengusaha sebanyak 7 orang (6,7 persen), dan pekerjaan lainnya sebanyak 9 orang $(8,6$ persen $)$.

Sebagian besar reponden berpendidikan terakhir SMA/sederajat mendominasi penelitian dengan jumlah sebanyak 73 orang $(69,5$ persen $)$, kemudian sisanya yaitu berpendidikan terakhir diploma sebanyak 4 orang (3,8 persen), S1 sebanyak 25 orang (23,8 persen), dan S2 sebanyak 3 orang (2,9 persen).

Reponden dalam penelitian ini sebagian besar beralamat di daerah Denpasar Selatan dengan jumlah 45 orang (42,8 persen), sedangkan sisanya berasal dari daerah Denpasar Barat sebanyak 24 orang (22,9 persen), Denpasar Timur sebanyak 19 orang (18,1 persen) dan daerah Denpasar Utara sebanyak 17 orang (16,2 persen).

Data dalam penelitian ini, pengujiannya menggunakan teknik analisis jalur (path analysis), dimana teknik analisis ini merupakan perluasan dari teknik analisis linier berganda untuk menguji hubungan kausalitas antara dua variabel atau lebih. Tahapan dalam teknik analisis jalur (path analysis) yaitu: 
Tabel 1.

Hasil Analisis Jalur Persamaan Regresi 1

\begin{tabular}{|c|c|c|c|c|c|}
\hline \multirow[t]{2}{*}{ Model } & \multirow{2}{*}{$\begin{array}{c}\text { Unstandardized } \\
\text { Coefficients } \\
\text { B } \\
\end{array}$} & \multicolumn{2}{|c|}{$\begin{array}{c}\text { Standardized } \\
\text { Coefficients }\end{array}$} & \multirow[t]{2}{*}{$\mathbf{T}$} & \multirow[t]{2}{*}{ Sig. } \\
\hline & & Std.Error & Beta & & \\
\hline 1(Constant) & 5,354 & 1,178 & & 4,544 & 0,000 \\
\hline Iklan & 0,264 & 0,041 & 0,534 & 6,411 & 0,000 \\
\hline
\end{tabular}

Sumber: Data diolah, 2016

Berdasarkan hasil analisis jalur (path analysis) substruktural 1 seperti pada data yang disajikan pada Tabel 1, maka persamaan strukturalnya adalah sebagai berikut:

$$
\mathrm{M}=\beta_{1} \mathrm{X}+\mathrm{e}_{1}
$$

$$
\mathrm{M}=0,534 \mathrm{X}+\mathrm{e}_{1}
$$

Tabel 2.

Hasil Analisis Jalur Persamaan Regresi 2

\begin{tabular}{lccccc}
\hline \multicolumn{1}{c}{ Model } & $\begin{array}{c}\text { Unstandardized } \\
\text { Coefficients }\end{array}$ & \multicolumn{2}{c}{$\begin{array}{c}\text { Standardized } \\
\text { Coefficients }\end{array}$} & T & Sig. \\
& B & Std.Error & Beta & & \\
\hline 1 (Constant) Iklan & $-0,486$ & 1,849 & & $-0,263$ & 0,793 \\
Kesadaran Merek & 0,401 & 0,070 & 0,458 & 5,756 & 0,000 \\
(Brand Awareness) & 0,671 & 0,141 & 0,379 & 4,757 & 0,000 \\
R2 $^{2}: 0,538$ & F Statistik : 59,466 & & Sig F : 0,000 & & \\
\hline
\end{tabular}

Sumber: Data diolah, 2018

Berdasarkan hasil analisis jalur (path analysis) substruktural 2 seperti pada

Tabel 2 diatas, maka persamaan strukturalnya adalah sebagai berikut:

$$
\begin{aligned}
& Y=\beta_{2} X+\beta_{3} M+e_{2} \ldots \ldots . \\
& Y=0,458 X+0,379 M+e_{2}
\end{aligned}
$$

Tabel 3.

Pengaruh Langsung dan Pengaruh Tidak Langsung serta Pengaruh Total Iklan (X), Kesadaran Merek (Brand Awareness) (M), Niat Beli (X)

\begin{tabular}{lccc}
\hline $\begin{array}{c}\text { Pengaruh } \\
\text { Variabel }\end{array}$ & $\begin{array}{c}\text { Pengaruh } \\
\text { Langsung }\end{array}$ & $\begin{array}{c}\text { Pengaruh Tidak Langsung Melaui } \\
\text { Kesadaran Merek (Brand Awareness })\end{array}$ & Pengaruh Total \\
$(\mathbf{M})(\boldsymbol{\beta 1} \mathbf{x ~} \boldsymbol{\beta 3})$ & \\
\hline $\mathrm{X} \rightarrow \mathrm{M}$ & 0,534 & - & 0,534 \\
$\mathrm{X} \rightarrow \mathrm{Y}$ & 0,458 & 0,202 & 0,660 \\
$\mathrm{M} \rightarrow \mathrm{Y}$ & 0,379 & - & 0,379 \\
\hline
\end{tabular}

Sumber: Data diolah, 2018 
Tabel 4.

Hasil Uji Sobel

\begin{tabular}{rc}
\hline Nilai $\mathbf{Z}$ & Sig \\
\hline 2,625 & 0,000 \\
\hline Sumber: Data diolah, 2018 &
\end{tabular}

Berdasarkan hasil pengujian hipotesis pada pengaruh iklan terhadap kesadaran merek (brand awareness) diperoleh nilai koefisien beta sebesar 0,534 dengan tingkat signifikansi $0,000(\leq 0,05)$ yang mengartikan bahwa $\mathrm{H}_{0}$ ditolak dan $\mathrm{H}_{1}$ diterima. Hal tersebut menujukkan bahwa iklan secara signifikan berpengaruh positif terhadap kesadaran merek (brand awareness). Jadi, jika semakin baik iklan smartphone Oppo maka kesadaran merek (brand awareness) konsumen di Kota Denpasar terhadap smartphone Oppo juga semakin meningkat. Dengan demikian dapat dikatakan iklan dapat mempengaruhi kesadaran merek (brand awareness) konsumen. Pengiklanan yang baik dengan pesan yang mudah diingat dan memiliki kreativitas yang tinggi akan menjadi daya tarik tersendiri terhadap suatu iklan sehingga konsumen akan mudah mengingat merek dari perusahaan yang pada akhirnya akan menciptakan kesadaran merek (brand awareness) dibenak konsumen.

Hasil penelitian ini mendukung penelitian dari Bimantoro dan Anita (2011) yang mengatakan bahwa frekuensi melihat iklan konsumen akan mempengaruhi tingkat kesadaran merek konsumen secara positif dan signifikan. Penelitian Sukma dkk. (2015) juga mengemukakan bahwa efektivitas iklan berpengaruh positif signifikan terhadap peningkatan brand awareness konsumen. Penelitian yang dilakukan oleh Sugiardi dan Harti (2017) juga menemukan bahwa secara keseluruhan iklan memberikan dampak yang positif dan signifikan terhadap brand awareness konsumen. 
Berdasarkan hasil pengujian hipotesis pada pengaruh iklan terhadap niat beli diperoleh nilai koefisien beta sebesar 0,458 dengan tingkat signifikansi sebesar $0,000(\leq 0,05)$ yang berarti bahwa $\mathrm{H}_{0}$ ditolak dan $\mathrm{H}_{1}$ diterima. Hal tersebut menujukkan bahwa iklan secara signifikan berpengaruh positif terhadap niat beli. Jadi, jika semakin baik iklan smartphone Oppo maka niat beli konsumen pada smartphone Oppo di Kota Denpasar juga semakin meningkat. Dengan demikian, dapat dikatakan iklan dapat mempengaruhi niat beli konsumen. Apabila pengiklanan produk suatu perusahaan dilakukan dengan kreativitas tinggi maka akan mampu menciptakan daya tarik konsumen pada iklan tersebut yang kemudian pada akhirnya menciptakan niat beli konsumen terhadap produk dari perusahaan tersebut.

Hasil penelitian ini mendukung penelitian dari Suharto dkk. (2016) yang mengatakan bahwa daya tarik iklan berpengaruh signifikan terhadap minat beli konsumen dengan arah yang positif. Penelitian Wibowo dan Nurhadi (2017) juga mengatakan bahwa terdapat pengaruh positif efektivitas iklan terhadap minat beli konsumen. Penelitian Husein dkk. (2017) juga menemukan bahwa variabel iklan berpengaruh secara positif dan signifikan terhadap minat beli konsumen.

Berdasarkan hasil pengujian hipotesis pada pengaruh kesadaran merek (brand awareness) terhadap niat beli diperoleh nilai koefisien beta sebesar 0,379 dengan tingkat signifikasi sebesar $0,000(\leq 0,05)$ yang berarti bahwa $\mathrm{H}_{0}$ ditolak dan $\mathrm{H}_{1}$ diterima. Hal ini menunjukan bahwa kesadaran merek (brand awareness) secara signifikan berpengaruh positif terhadap niat beli. Jadi, jika semakin tinggi kesadaran merek (brand awareness) konsumen terhadap smartphone Oppo maka 
niat beli konsumen pada smartphone Oppo juga semakin meningkat. Dengan demikian, dapat dikatakan bahwa kesadaran merek (brand awareness) berpengaruh terhadap niat beli konsumen. Kesadaran merek (brand awareness) memegang peranan penting terhadap niat beli konsumen karena kesadaran merek (brand awareness) merupakan langkah awal dari niat beli konsumen. Jika konsumen memiliki kesadaran merek (brand awareness) yang tinggi terhadap suatu produk maka konsumen akan merasa yakin bahwa merek dari produk tersebut merupakan satu-satunya dalam kategori suatu produk. Sehingga dari kesadaran merek (brand awareness) yang tinggi di benak konsumen tersebut akan mencipatakan niat beli konsumen terhadap suatu produk.

Hasil penelitian ini mendukung penelitian dari Petahiang et al. (2015) yang mengatakan bahwa kesadaran merek berdampak positif dan signifikan terhadap niat beli konsumen. Penelitian dari Iwan dan Kaman (2017) juga menemukan bahwa brand awareness memiliki pengaruh yang positif dan signifikan terhadap minat beli konsumen. Penelitian dari Prabawa dkk. (2017) juga mengatakan bahwa brand awareness secara signifikan berpengaruh positif terhadap niat beli konsumen.

Berdasarkan pengujian hipotesis pada peran kesadaran merek (brand awareness) dalam memediasi iklan terhadap niat beli diperoleh nilai koefisien beta sebesar 0,660 dengan tingkat signifikansi sebesar $0,000(\leq 0,05)$ yang berarti $\mathrm{H}_{0}$ ditolak dan $\mathrm{H}_{1}$ diterima. Hal tersebut menunjukkan bahwa kesadaran merek (brand awareness) mampu memediasi pengaruh iklan terhadap niat beli secara positif dan signifikan. Dengan kata lain, kesadaran merek (brand awareness) mampu memperkuat pengaruh iklan terhadap niat beli yang semula diperoleh nilai koefisien 
beta sebesar 0,458 kemudian setelah ditambahkan kesadaran merek (brand awareness) sebagai variabel mediasi pengaruh iklan terhadap niat beli, nilai koefisien beta meningkat menjadi 0,660. Sehingga dapat dikatakan kesadaran konsumen terhadap merek Oppo mampu meningkatkan niat beli konsumen pada smartphone Oppo yang awalnya tertarik dan berniat membeli smartphone Oppo karena pengaruh dari melihat iklan smartphone Oppo. Jika konsumen telah memiliki kesadaran terhadap merek Oppo dan melihat iklan smartphone Oppo maka niat beli konsumen pada smartphone Oppo lebih tinggi jika dibandingkan dengan konsumen yang hanya melihat iklan smartphone Oppo.

Hasil penelitian ini mendukung penelitian dari Herdana (2015) yang mengatakan bahwa iklan berpengaruh positif dan signifikan terhadap brand awareness. Penelitian dari Gunawan dan Diah (2014) yang juga mengatakan bahwa iklan sebagai media promosi terbukti memiliki hubungan positif signifikan serta berperan penting meningkatkan kesadaran merek (brand awareness), selain itu mereka juga mengatakan bahwa terdapat pengaruh positif dan signifikan antara iklan dan minat beli konsumen. Penelitian Yudihartika dan Haryanto (2012) juga menemukan bahwa kesadaran merek berpengaruh positif signifikan terhadap niat membeli konsumen. Secara tidak langsung penelitian dari Prabawa dkk. (2017) mengatakan bahwa kesadaran merek (brand awareness) mampu memediasi hubungan iklan dengan niat beli secara positif dan signifikan.

Tabel 5.

Hasil Pengujian Koefisien Determinasi Total

\begin{tabular}{lcl}
\hline Hasil Pengujian & Koefisien Determinasi & \multicolumn{1}{c}{ Keterangan } \\
\hline $\mathrm{R}^{2} \mathrm{~m}$ & 0,243 & $\begin{array}{l}\text { Pengaruh variabel bebas terhadap } \\
\text { variabel terikat secara gabungan }\end{array}$ \\
\hline
\end{tabular}

Sumber: Data diolah, 2018 
Nilai determinasi total sebesar 0,243 mempunyai arti bahwa sebesar 24,3 persen variabel niat beli dipengaruhi oleh variabel iklan dan kesadaran merek (brand awareness), sedangkan sisanya sebesar 75,7 persen dijelaskan oleh faktor lain yang tidak dimasukkan dalam model.

Implikasi dalam penelitian ini dapat memperkuat penelitian sebelumnya dan menjadi referensi mengenai hubungan antara iklan, kesadaran merek (brand awareness) dan niat beli baik secara langsung maupun tidak langsung. Hipotesis dalam penelitian terbukti, dimana iklan dan kesadaran merek (brand awareness) mampu mempengaruhi niat beli secara positif dan signifikan. Iklan merupakan salah satu jenis promosi yang dapat digunakan oleh perusahaan dalam memperkenalkan produknya hingga menarik minat konsumen. Penggunaan media dan penyampian pesan yang tepat merupakan beberapa faktor perlu diperhatikan oleh setiap perusahaan dalam melakukan pengiklanan produk. Penggunaan strategi yang tepat dalam pengiklanan produk suatu perusahaan maka akan mampu menarik minat konsumen. Berawal dari ketertarikan konsumen pada sebuah iklan, apabila konsumen melihat suatu iklan dengan frekuensi yang tinggi akan memunculkan ingatan dalam benaknya mengenai merek dari produk tersebut. Melalui iklan konsumen juga dapat tertarik untuk membeli sebuah produk sehingga iklan merupakan salah satu jenis promosi yang wajib digunakan suatu perusahaan agar mampu menciptakan kesadaran merek (brand awareness) dan niat beli konsumen. Oppo sebagai perusahaan yang terbilang baru dalam bisnis smartphone di Indonesia penting untuk selalu memperhatikan dalam penerapan strategi pengiklanan. Strategi pengiklanan yang tepat dengan mempertimbangkan berbagai aspek seperti 
pesan iklan, pemilihan media yang tepat dan penyajian iklan yang menarik akan memunculkan kesadaran merek (brand awareness) konsumen. Konsumen yang sadar terhadap merek Oppo maka akan menciptakan kepercayaan konsumen pada merek Oppo yang akhirnya memunculkan niat beli konsumen pada smartphone Oppo.

Beberapa keterbatasan yang terdapat dalam penelitian ini yaitu ruang lingkup dalam penelitian hanya terbatas di Kota Denpasar saja, sehingga penelitian ini tidak dapat digeneralisasi untuk daerah yang lebih luas. Jumlah responden yang terbatas dikarenakan keterbatasan biaya dan waktu. Penelitian ini dilakukan dalam titik waktu tertentu sehingga perlu dilakukan penelitian kembali di masa mendatang, hal tersebut dikarenakan lingkungan yang dapat berubah-ubah setiap saat atau bersifat dinamis.

\section{SIMPULAN DAN SARAN}

Berdasarkan hasil pembahasan dalam penelitian yang telah dilakukan, maka dapat disimpulkan bahwa iklan berpengaruh secara positif dan signifikan terhadap kesadaran merek (brand awareness). Hal ini menunjukkan bahwa semakin baik iklan smartphone Oppo maka akan semakin tinggi kesadaran merek (brand awareness) konsumen di Kota Denpasar terhadap smartphone merek Oppo.

Iklan berpegaruh secara positif dan signifikan terhadap niat beli. Hal ini menunjukkan bahwa semakin baik iklan smartphone Oppo maka akan semakin tinggi niat beli konsumen di Kota Denpasar pada smartphone Oppo.

Kesadaran merek (brand awareness) berpengaruh secara positif dan signifikan terhadap niat beli. Hal ini menunjukkan bahwa semakin tinggi kesadaran 
merek (brand awareness) konsumen terhadap merek Oppo maka akan semakin tinggi niat beli konsumen di Kota Denpasar pada smartphone Oppo.

Kesadaran merek (brand awareness) berpengaruh secara positif dan signifikan dalam memediasi hubungan iklan dengan niat beli. Hal ini menunjukkan bahwa kesadaran merek (brand awareness) yang terdapat dibenak konsumen terhadap merek Oppo mampu meningkatkan pengaruh iklan smartphone Oppo terhadap niat beli konsumen di Kota Denpasar pada smartphone Oppo.

Beberapa saran yang dapat disampaikan dalam penelitian ini adalah pihak Oppo Electronics Corp, Ltd. sebaiknya dalam mengiklankan produk membuat iklan yang lebih menarik dan lebih memperlihatkan sisi keunggulan produk untuk meningkatkan niat beli konsumen terhadap produk smartphone Oppo.

Pihak Oppo Electronics Corp, Ltd. sebaiknya menciptakan slogan yang lebih mudah diingat dan berbeda dari pesaing lainnya agar mampu meningkatkan top of mind di benak konsumen.

Bagi penelitian selanjutnya diharapkan dapat dilakukan pada cakupan wilayah yang lebih luas dan dapat ditambahkan variabel bebas lain yang dapat mempengaruhi niat beli seperti kualitas produk, country of origin, word of mouth dan variabel-variabel lainnya.

\section{REFERENSI}

Aaker, David A. 2013. Manajemen Pemasaran Strategis. Jakarta: Salemba Empat. Andrologi, Febrian. 2014. Analisis Pengaruh Brand Image dan Brand Awareness Terhadap Brand Loyalty dan Dampaknya Terhadap Brand Equity. Skripsi. Semarang: Fakultas Ekonomika dan Bisnis Universitas Diponogoro.

Annafik, A. F., dan M. Raharjo. 2012. Analisis Pengaruh Kualitas Produk, Harga dan Daya Tarik Iklan Terhadap Niat Beli Sepeda Motor Yamaha (Studi Kasus 
Pada Konsumen Yamaha SS Cabang Kudungmundu Semarang). Journal of Management, 1(2), hal.274-281.

Aprilisya, Eka. 2016. Peran Sikap Memediasi Pengaruh Pemasaran Hijau Terhadap Niat Beli Produk Ramah Lingkungan. Skripsi Sarjana Jurusan Manajemen Pada Fakultas Ekonomi dan Bisnis Universitas Udayana, Bali.

Assagaf, Fatmah. 2013. The Effect of Advertising on Consumer Decision Making Trough Brand Brand Awareness. Jurnal EMBA, 1(4), pp.866-874.

Bimantoro, Forddhanto., dan F. Anita Herawati. 2011. Pengaruh Frekuensi Melihat Iklan Floating Terhadap Tingkat Kesadaran Merek. Jurnal Ilmu Komunikasi, $8(2)$.

Charanah, J., and R. K. Njuguna. 2015. The Effects of Promotional Mix Tools on Brand Equity Among Hospitals in Nairobi Country. International Journal of Sales, Retailing And Marketing, 4(6), pp.45-51.

Fatmawati, S. R. N., dan Yoestini. 2012. Analisis Iklan dan Endorser Terhadap Pembentukan Brand Awareness Serta Dampaknya Pada Keputusan Beli Produk Kecap Manis ABC. Diponogoro Journal of Management, 1(1), hal.456-461.

Hasbun, Budiharto., dan Endang Ruswanty. 2016. Komperasi Antara Kelompok yang Melihat Iklan dengan Brand Awareness Terhadap Niat Beli (Studi Pada Commuter Line). Journal of Business Studies, 2(1).

Herdana, A. 2015. Analisis Pengaruh Brand Awareness Pada Produk Asuransi Jiwa Prudential Life Assurance (Studi Pada Pru Passion Agency Jakarta). Jurnal Riset Bisnis dan Manajemen, 3(1), hal.1-18.

Huang, Ying-Fang., and Hoang Sa Dang. 2014. An Empirical Analysis on Purchase Intention on Coffee Beverage in Taiwan. European Journal of Business and Management, 6(36), pp.182-196.

Husein, Andrio., Zulkarnain., dan Taufiqurrahman. 2017. Analisis Pengaruh Iklan dan Celebrity Endorser Terhadap Citra Merek dalam Meningkatkan Minat Beli Shampoo Pentene Pada Masyarakat Kota Pekanbaru. Jurnal Online Mahasiswa (JOM), 4(1), hal.243-256.

Iwan., dan Kaman Nainggolan. 2017. Pengaruh Celebrity Endorder, Brand Awareness dan Harga Produk Terhadap Minat Beli Mie Sukses (Studi Empiris Pada Penduduk Kecamatan Pinang-Kota Tanggerang). Cakrawala, 17(2), hal.146-155. 
Jalilvand, M. R., Neda Samiei., and S. H. Mahdavinia. 2011. The Effect of Brand Equity Component on Purchase Intention: An Application of Aaker's Model in The Automobile Industry. International Business and Management, 2(2), pp.149-158.

Jefkins, Frank. 1997. Periklanan. Edisi Ketiga. Jakarta: Erlangga.

Kalele, Billiclinton., Sem G. Oroh., dan Jacky Sumarauw. 2015. Pengaruh Word of Mouth, Daya Tarik Iklan, Persepsi Harga dan Kualitas Produk Terhadap Minat Beli Motor Suzuki Satria FU Pada PT. Sinar Galesong Mandiri. Jurnal EMBA, 3(3), hal.451-462.

Karunanithy, M., and Sivesan S. 2013. A Empirical Study on The Promotional Mix and Brand Equity: Mobile Service Providers. Industrial Engineering Letters, 3(3), pp.1-9.

Keke, Yulianti. 2015. Komunikasi Pemasaran Terpadu Terhadap Brand Awareness. Jurnal Manajemen Bisnis Transportasi dan Logistik, 2(1), hal.172-186.

Kotler, P., and K. L. Keller. 2012. Marketing Management, $13^{\text {th }}$ Edition. New Jersey: Pearson Education, Inc.

Malik, M. E., M. Mudasar Ghafoor., and Hafiz Kashif Iqbal. 2013. Importance of Brand Awareness and Brand Loyalty in Assessing Purchase Intentions of Consumer. International Journal of Business and Social Science, 4(5), pp.167-171.

Merriska, A., and Purwanegara, M. S. 2012. The Relationship Between TV Advertising Cost and Brand Awareness for Food Product Category in Indonesia (February 2010). Journal of Business and Management, 1(1), pp.90-94.

Niken. 2007. Manajemen Periklanan. Jakarta: PT. Pustaka Utama Grafiti.

Odunlami, Ibojo Bolanle., and Akinruwa T. E. 2014. Effect of Promotion on Product Awareness (A Case Study of A Reputable Organization in The Brewery Sub-Sector of The Manufacturing Industry). International Journal of Education and Research, 2(9), pp.451-472.

Petahiang, I. L., Peggy Mekel., and F. G. Worang. 2015. The Influence of Brand and Perceived Risk Toward Consumer Purchase Intention on Online Store. Jurnal Berkala Ilmiah Efisiensi, 15(4), pp.120-135.

Prabawa, Teddy Surya., Raka Sukawati., dan Yudi Setiawan. 2017. Peran Brand Awareness dalam Memediasi Hubungan Iklan dan Personal Selling dengan Niat Beli. E-Jurnal Manajemen Unud, 6(2), hal.889-918. 
Priya, Pankaj., Rajat Kanti Baisya., and Seema Sharma. 2010. Television Advertisements and Children's Buying Behaviour. Marketing Intelligence \& Planning, 28(2), pp.151-169.

Riduwan dan Engkos Achmad Kuncoro. 2011. Cara Menggunakan dan Memakai Path Analysis (Analisis Jalur). Bandung: Alfabeta.

Roozy, E., M. Ali Arastoo., and H. Vazifehdust. 2014. Effect of Brand Equity on Consumer Purchase Intention. Indian J.Sci.Res, 6(1), pp.212-217.

Sawant, R. P., and Roshi P. 2012. Impact of Advertising on Brand Awareness and Consumer Preference (with Special Reference to Men'S Wear). Journal of Business and Management (IOSR-JBM ), 5(6), pp.54-61.

Schiffman, Leon G., dan Leslie Lazar Kanuk. 2004. Perilaku Konsumen. Edisi Ketujuh. Jakarta: Prentice Hall.

Shah, Syed Saad Hussain., J. Aziz., A. R. Jaffari., S. Weris., W. Ejaz., M. Fatima., and S. K. Sherazi. 2012. The Impact of Brand on Consumer Purchase Intentions. Asian Journal of Business Management, 4(2), pp.105-110.

Sramova, Blandina. 2015. Marketing and Media Communications Targeted to Children As Consumers. Procedia - Social and Behavioral Sciences, 191, pp.1522-1527.

Sugiardi, Agustin Bayu., dan Harti. 2017. Pengaruh Iklan dan Atribut Produk Terhadap Brand Awareness Pada Produk Hufagripp. Jurnal Pendidikan Tata Niaga (JPTN), 3(3), hal.30-35.

Suharto, Clifen. A. A., Altje L. Tumbel., dan Irvan Trang. 2016. Analisis Pengaruh Citra Merek, Harga dan Daya Tarik Iklan Terhadap Minat Beli Konsumen Pada PT. Remaja Jaya Mobilindo Manado. Jurnal EMBA, 4(3), hal.209-221.

Sukma, F., M. Sarma., dan M. Syamsum. 2015. Efektivitas Iklan dalam Menumbuhkan Brand Awareness SMA Sampoerna, Manajemen IKM, 10(2), hal.182-193.

Sulistyowati, Fitria A. 2013. Pengaruh Brand Awareness dan Kualitas Produk Terhadap Brand Attitude Produk Pureit dari Unilever. Skripsi Fakultas Ekonomi dan Bisnis Universitas Brawijaya, Malang.

Suprapti, N. W. Sri. 2010. Perilaku Konsumen: Pemahaman Dasar dan Aplikasinya dalam Strategi Pemasaran. Denpasar: Udayana University Press. 
Susilo, Irene., dan Hatane Samuel. 2015. Analisa Pengaruh Emotional Marketing Terhadap Purchase Intention Melalui Brand Awareness Pada Produk Dove Personal Care di Surabaya. Jurnal Manajemen Pemasaran, 9(1), hal.23-34.

Swastha, Basu., dan Irawan. 2005. Manajemen Pemasaran Modern. Edisi Kedua. Yogyakarta: Liberty.

Swisstiani, Febby. 2014. Pengaruh Persepsi Harga, Efektivitas Iklan Internet dan Promosi Penjualan Terhadap Minat Beli Konsumen Pada Toko Online Zalora. Skripsi Sarjana Jurusan Manajemen Pada Fakultas Ekonomi Universitas Negeri Yogyakarta, Yogyakarta.

Tjiptono, F. 2005. Pemasaran Jasa. Malang: Bayumedia Publishing.

Tulasi, D. 2012. Marketing Communication dan Brand Awareness. Humaniora, 3(1), hal.215-222.

Wells, William., Sandra Moriarty., and John Burnett. 2006. Advertising: Principles $\&$ Practice, $7^{\text {th }}$ ed. New Jersey: Pearson Prentice Hall.

Wen, Ling-Yu Melody., and Shang-Hui Li. 2013. Consciousness, Ecological Affect, and Purchase Intention of Green Production. Journal of Organizational Innovation, 5(4), pp.124-137.

Wibowo, Bayu Mukti., dan Nurhadi. 2017. Pengaruh Kualitas Produk, Efektivitas Iklan, dan Celebrity Endorser Terhadap Minat Beli Sandal (Studi Pada Sandal Homypad Versi Iklan Raffi Ahmad dan Soimah di Fakultas Ekonomi Universitas Yogyakarta). Jurnal Manajemen Bisnis Indonesia (JMBI), 6(1), hal.1-11.

Yaseen, N., M. Tahira., A. Gulzar., and A. Anwar. 2011. Impact of Brand Awareness, Perceived Quality and Consumer Loyalty on Brand Profitability and Purchase Intention: A Resellers' Views. Interdisciplinary Journal of Contemporary Research in Business, 3(8), pp.833-839. 